\title{
ADAT PERNIKAHAN DAYAK TOBAG TINJAUAN ANTROPOLINGUISTIK
}

\section{INDIGENOUS MARRIAGE DAY OF TOBAG ANTHROPOLINGUISTIC REVIEW}

\author{
Martina \\ Balai Bahasa Kalimantan Barat \\ aan_martina@yahoo.com
}

\begin{abstract}
ABSTRAK
Penelitian ini berjudul Adat Pernikahan Dayak Tobag Tinjauan Antropolinguistik. Masalah dalam penelitian ini bagaimana kajian antropolinguistik mampu membedah suatu tradisi dan menghasilkan suatu analisis yang apik dari hubungan keduanya. Dalam pembahasan ada tiga pendekatan utama dalam kajian antropolinguistik yaitu performansi (performance), indeksikalitas (indexicalty), partisipasi (participation),yang terbukti efektif dalam mengkaji hubungan struktur teks, koteks dan konteks (budaya, ideologi, sosial, dan situasi) suatu tradisi yang dilatarbelakangi unsur-unsur budaya dan aspek kehidupan manusia yang berbedabeda. Kajian antropolinguistik, yaitu penekanan antropolinguistik dalam menggali makna, fungsi, nilai, norma, dan kearifan lokal suatu tradisi lisan, konsep ketiganya dapat dibedakan. Lebih dari pada itu, pendekatan antropolinguistik mampu merumuskan model revitalisasi dan pelestarian suatu tradisi lisan. Dalam hal inilah ciri pembeda kajian antropolinguistik dengan pendekatan yang lain terlihat kuat dan menonjol. Metode yang digunakan adalah deskriptif analisis dengan pendekatan kualitatif. Penelitian ini merupakan kajian literatur yang didukung dengan berbagai hasil penelitian. Hasil analisis menunjukkan bahwa kearifn lokal dalam tradisi pernikahan Dayak Tobag dikenal istilah sanggan bebayo', tonya' menonya', betunang, kebabar), pernikahan (beloki bebini mbio lopas, beloki bebini bepipis becale'k abis man manu'k, beloki bebini ponoh, beloki bebini), dan hukum adat pascapernikahan terbagi menjadi empat, yaitu adat masalah pergaulan dan komunikasi (adat timpak kemata labat ka oti, adat nganggoh, adat betama'k kediri, adat nggagap), ada mas tujuh, adat sara'k atau penceraian (sara'k ingka', sara'k siko'nngi suka, sara'k timpak, sara'k rangkak, nula'k loki/bini dan besait besasat), dan adat amar (amar lawing agong adat, amar pesirah adat, amar jata adat, amar temenggung adat, dan amar pati adat).
\end{abstract}

Kata kunci: adat, pernikahan, antropolinguistik

\section{ABSTRACT}

This research was Indigenous Marriage Day of Tobag, Anthropolinguistic Review. The problem in this study is how anthropolinguistic studies are able to dissect on tradition and produce a neat analysis of the relationship between the two. In the discussion there are three main approaches in the study of anthropolinguistics, namely the performance (performance), indexicality (indexicalty), participation (participation), which proved effective in examining the relationship of text structure, context and context (culture, ideology, social, 
Tuah Talino

Tahun XIV Volume 14 Nomor 1 Edisi 31 Juli 2020

ISSN 0216-079X E-ISSN 2685-3043

Balai Bahasa Kalimantan Barat

and situation) an oral tradition which is based on different cultural elements and aspects of human life. Anthropolinguistic studies, namely the emphasis of anthropolinguistics in exploring the meaning, function, values, norms, and local wisdom of an oral tradition, the concept of all three can be distinguished. More than that, the anthropolinguistic approach is able to formulate a model of revitalization and preservation of an oral tradition. In this case the distinguishing features of anthropolinguistic studies with other approaches are strong and prominent. The method used is descriptive analysis with a qualitative approach. This research is a literature or literature study which is supported by various research results. The results of the analysis show that local wisdom in the tradition terms sanggan bebayo', tonya' menonya ', betunang, kebabar), (beloki bebini mbio lopas, beboki bebini bepipis becale'k abis man manu'k, beboki bebini ponoh, beloki bebini), and customary law are divided into four, namely customary social relations and issues (adat timpak kemata labat ka oti, nganggoh adat, betama'k kediri custom, nggagap custom), there are seven mas, adat sara'k or divorce (adat adat tabat kemabat labat oti, adat nganggoh, adat betama'k kediri, adat nggagap), there are seven mas, adat sara'k or divorce (adat adat). sara'k ingka', sara'k siko'nngi like, sara'k timpak, sara'k creep, nula'k loki/chant and hand in hand), and adat amar (amar lawing agong adat, amar pesirah adat, amar jata crawl adat, amar temenggung adat, and amar pati adat).

Keywords: custom, marriage, anthropolinguistics

\section{PENDAHULUAN}

Kalimantan Barat memiliki keberagaman adat-istiada di setiap kabupatennya. Keanekaragaman yang ada merupakan potensi budaya yang dapat membentuk karakter potensi dan citra budaya tersendiri pada tiap suku bangsa serta bagian penting bagi pembentukan citra dan identitas budaya suatu daerah. Selain itu, keanekaragaman merupakan kekayaan intelektual dan kultural dari warisan budaya yang perlu dilestarikan. Menurut Endraswara (2018: 233) budaya sebagai warisan sosial manusia dan bagian buatan manusia. Pada dasarnya, segala bentuk perilaku yang diperoleh melalui pembelajaran. Perilaku manusia berbudaya biasanya berpola sesuai dengan norma-norma yang disepakati atau konvensi masyarakat https://scholar.google.co.id/scholar?q=penelitian+Endraswara+(2018:+233)\&hl=e n\&as_sdt=0\&as_vis=1\&oi=scholart.

Budaya merupakan adat istiadat atau sesuatu mengenai kebudayaan yang sudah berkembang di dalam masyarakat. Menurut Hall (Liliweri, 2016: 84), kebudayaan sebagai cara hidup sejumlah orang, totalitas dari pola-pola perilaku yang dipelajari, sikap, dan hal-hal yang bersifat material. Jadi yang namanya cara hidup, totalitas pola-pola perilaku, sikap, dan material merupakan bahasa (pesan) tentang kebudayaan. Pernyataan Hall sejalan dengan Kluckhohn bahwa dalam setiap kebudayaan selalu ada sistem nilai budaya yang dapat dikenal melalui lima masalah dasar kehidupan manusia (dalam Liliweri, 2016: 61). Lima masalah tersebut terkait hakikat, yaitu hakikat hidup manusia, karya manusia, kedudukan manusia dalam ruang waktu, hubungan manusia dengan alam sekitar, dan hubungan manusia dengan sesamanya. Willems (Arman dalam Basri, 2018: 324) 
Tuah Talino

Tahun XIV Volume 14 Nomor 1 Edisi 31 Juli 2020

ISSN 0216-079X E-ISSN 2685-3043

Balai Bahasa Kalimantan Barat

mengaminkan pendapat pakar sebelumnya bahwa dalam tradisi lisan mengandung fakta budaya berupa religi, sistem genealogi dan kosmogoni, sejarah, filsafat, etika, moral, sistem pengetahuan dan kaidah-kaidah kebahasaan serta kesusastraan. Begitu juga dengan Liliweri (2014: 18) menyebutkan bahwa tujuan kebudayaan itu sangat luas karena di dalamnya ada filosofi, nilai-nilai, dan cara hidup dari suatu masyarakat atau bangsa.

Untuk mengungkap adat istiadat yang dibungkus dalam bingkai budaya atau kebudayaan, diperlukan alat untuk membedahnya melalui antropologi linguistik. Melalui antropologi linguistik inilah suatu sistem budaya bisa dijelaskan. Terkait adat-istiadat dalam masyarakat perlu ditelaah maknanya. Melalui antropoliustik, kajian ini akan membedah dan menelaah tentang budaya, tradisi, bahasa yang digunakan oleh manusia. Berdasarkan KBBI (2014: 1423), telaah memiliki makna penyelidikan, kajian, pemeriksaan, atau penelitian. Sedangkan linguistik adalah ilmu tentang bahasa, telaah bahasa secara ilmiah (KBBI, 2014:832). Linguistik atau bahasa adalah bunyi-bunyi bahasa yang dihasilkan dalam bentuk ujaran yang selalu dikaitkan dengan fakta nyata yang ada hubungannya dengan kehidupan manusia, Busri dan Moh. Badrih (2018: 43). Terkait bahasa, Muniah menyatakan bahwa bahasa dijadikan sarana untuk menciptakan karya sastra dapat dilihat perkembangannya. Bahasa sebagaimana juga budaya merupakan bagian tak terpisahkan dari diri manusia sehingga kita cenderung menganggapnya diwariskan secara turun-temurun (2015:171). Komunikasi yang dilakukan antaretnis memerlukan penyesuaian satu dengan lainnya. Penyesuaian dapat dilakukan dengan penguasaan bahasa atau budaya dari masing-masing etnis. Nilai-nilai dalam kehidupan seperti nilai ekonomi, pendidikan, sosial, dan lainnya menjadi dasar penciptaan suatu karya yang merupakan hasil pemikiran manusia pada suatu komunitas budaya suatu tempat.

Terkait kegiatan budaya yang masih dilestarikan dalam masyarakat khususnya tradisi pernikahan Dayak Tobag, diperlukan bahasa sebagai pegungkap dalam menelaah makna sakral di dalamnya. Fungsi bahasa ini memegang peran penting dalam pengungkapan nilai-nilai yang terkandung di dalam budaya yang ada. Selain, bahasa yang menjadi pisau telaah penelitian ini, peneliti juga menggunakan pendekataan antropolinguistik di dalamnya. Oleh karena itu, peneliti memandang perlu untuk menelaah makna-makna yang tersirat dan tersurat di dalam tradisi atau adat pernikahan Dayak Tobag ini.

Penelitian ini akan mengungkap adat yang dilakukan secara turun-temurun oleh masyarakat Dayak Tobag khususnya dalam tradisi pernikahan. Masalah yang diangkat adalah bagaimana penggunaan istilah dan maknanya yang terkandung dalam tradisi pernikahan Dayak Tobag ditinjau dari antropolinguistik. Tujuannya untuk mendeskripsikan istilah-istilah yang digunakan dan makna yang terkandung di dalamnya. Penelitian ini lebih menitikberatkan pada kajian tentang istilah dan pemakmanaan yang digunakan pada tradisi pernikahan Dayak Tobag. Istilah adalah kata atau frasa yang dipakai sebagai nama atau lambang dan yang dengan cermat mengungkapkan makna konsep, proses, keadaan, atau sifat yang khas dalam bidang ilmu pengetahuan, teknologi, dan seni (Pusat Bahasa: 2007)

Dayak Tobag merupakan subsuku Dayak yang berada di kawasan Kabupaten Sanggau. Cikal-bakal terbentuknya subsuku Dayak tersebut pada 
jaman Bagaleh Ancok Arok, yaitu masa kepua' kabo. Ketidakcocokan antarkelompok manusia yang akhirnya membuat suku baru. Jaman begaleh ancok arok merupakan masa perpindahan mulai abad 50 sebelum masehi. Perpindahan itu awalnya diakibatkan ketidakcocokan dalam suatu kelompok terkait cara dan tradisi. Perbedaan diantara kelompok sudah ada sejak pengetahuan baru yang didapat mereka. Diperkirakan abad ke-30 sebelum masehi, perpecahan besar terjadi pada keluarga rumpun benua besar atau dikenal dengan sebutan benua aya. Bепиа aya ini adalah laman benua bumbun maya, rumpun tersebut dikenal sekarang sebagai rumpun Klemantan atau rumput laut. Penamaan tersebut didasarkan hidup di pesisir pantai laut atau di tepi sungai hanya sedikit yang di darat.

Nama Dayak Tobag dalam masyarakat Dayak Mali dikenal dengan Daya' Tobak atau Daya' Tabak, Daya' Tebang (bahasa laut, Melayu, Senganan), Daya' Tobang (Dayak Desa), dan Daya' Tobakng (Dayak Bukit). Perbedaan penamaan secara fonologi tersebut dilatarbelakangi keahlian dan kemampuan masyarakat adatnya dalam menebang kayu. Pada zaman baru, Dayak Tobag berdasarkan catatan "Buku Sejarah Kalimantan" JU Lontaan, Dayak Tobag dikenal dengan sebutan Daya Tebang yang berada di wilayah Benua Raya dan Benua Maku' Kapuas, dan Daya Cempedek berada di wilayah Benua Sepode' serta Benua Labai Lawai. Setelah musyawarah adat Dayak Tobag yang pertama (MUSDAT-DT 1) di pulau Tayan taggal 26 Maret 1994; dengan garis keturunan, mitologi, hukum adat, dan adat istiadat, akhirnya disepakati Daya Tebang dan Daya Cempedek adalah satu serta disebut dengan nama Daya' Tobak.

Berdasarkan hasil Musdat tersebut, ditetapkan benua adat Dayak Tobak terbagi 7 benua pati, yaitu benua Raya, benua Damang Ria, benua Mangku Kamint, benua Jaya Sempurna, benua Sepode', benua Kapuas Jaya, benua Labai Lawai. Setelah musyawarah adat ke -IX (Musdat-DT IX) disusun di Embaloh, Desa Tanjung Bunut, Tayan tanggal 30 Mei 2014, nama dan penulisan semula Daya' Tobak menjadi Dayak Tobag atas dasar makna dan pengucapan (dialek) dari tinjauan berbagai bahasa daerah.

Penelitian serupa pernah dilakukan oleh Robert Sibarani (2015) tentang Tradisi Lisan Menggunakan Pendekatan Antropolinguistik. Menurutnya dalam antropologi linguistik (linguistic anthropology) merupakan bidang ilmu interdisipliner yang mempelajari hubungan bahasa dengan seluk-beluk kehidupan manusia termasuk kebudayaan sebagai seluk-beluk inti kehidupan manusia. Dalam berbagai literatur, terdapat juga istilah linguistik antropologi (anthropological linguistics), linguistik budaya (cultural linguistics), dan etnolinguistik (ethnolinguistics). Meskipun ada penekanan tertentu yang membedakan keempat istilah tersebut, pada hakikatnya kajian-kajian keempat istilah tersebut tidak bisa dipisahkan, saling mengisi, dan saling melengkapi, bahkan sering tumpang tindih. Hal itu berarti bahwa keempat istilah itu mengacu pada kajian yang hampir sama walapun harus diakui bahwa istilah antropologi linguistik (linguistic anthropology) lebih sering digunakan di antara istilah itu.

Studi bahasa dalam bidang antropolinguistik dikaitkan dengan peran bahasa dalam seluk-beluk kehidupan manusia. Karena kebudayaan merupakan aspek yang paling dominan atau paling inti dalam kehidupan manusia, segala 
hierarki kajian bahasa dalam bidang antropolinguistik lebih sering dianalisis dalam kerangka kebudayaan.Studi bahasa ini disebut dengan memahami bahasa dalam konteks budaya. Studi budaya dalam bidang antropolinguistik berarti memahami seluk_beluk budaya dari kajian bahasa atau memahami kebudayaan melalui bahasa dari sudut pandang linguistik. Aspek-aspek lain kehidupan manusia selain kebudayaan seperti politik, religi, sejarah, dan pemasaran juga dapat dipelajari melalui bahasa sehingga hal itu juga menarik dalam kajian antropolinguistik. Atas dasar itu, antropolinguistik tidak hanya mengkaji bahasa, melainkan juga budaya dan aspek-aspek lain kehidupan manusia. Namun, ketika mengkaji budaya dan aspek-aspek kehidupan manusia, antropolinguistik mempelajarinya dari bahasa atau teks lingual. "Jalan masuk" (the entry point) kajian antropolinguistik adalah bahasa dan kemudian dapat "menjelajahi" kebudayaan dan aspek-aspek lain kehidupan manusia itu secara menyeluruh. Ketika antropolinguis mengkaji kesopansantunan sebagai bagian dari kebudayaan, dia dapat mempelajari praktik. Sibarani menyimpulkan bahwa antropolinguistik mengkaji tradisi lisan dalam beberapa tahapan. Tahapan pertama mengkaji bentuk tradisi lisan, yakni keterhubungan (interconnection)teks, ko-teks, dan konteks dalam suatu performansi untuk menemukan struktur, formula atau pola tradisi lisan. Tahapan berikutnya mengkaji isi tradisi lisan, yakni kebernilaian (valuability)yang merupakan makna dan fungsi, nilai dan norma, serta kearifan lokal sebuah tradisi lisan. Tahapan berikutnya mengkaji dan merumuskan model revitalisasi dan pelestarian tradisi lisan. Oleh karena itu, peneliti tertarik untuk mengkaji adat pernikahan Dayak Tobag di tinjau dari antropolinguistik.

\section{METODE}

Penelitian ini menggunakan pendekatan deskriptif kualitatif. Moleong (dalam Harianah, 2015:143) menjelaskan bahwa penelitian kualitatif adalah tradisi tertentu dalam ilmu pengetahuan sosial yang secara fundamental bergantung pada pengamatan terhadap manusia dalam kawasannya sendiri dan berhubungan dengan orang-orang tersebut dalam bahasa dan dalam peristilahannya. Menurut Denzim dan Lincoln (dalam Ahmadi, 2014:17), penelitian kualitatif adalah multimetode dalam fokus, termasuk pendekatan interpretif dan naturalistik terhadap pokok persoalannya. Hal tersebut mengisyaratkan bahwa penelitian kualitatif mempelajari segala sesuatu dalam latar alamiah, berusaha untuk memahami atau menginterpretasi fenomina dalam hal makna-makna yang orang-orang berikan pada fenomena tersebut. Lebih lanjut Denzim dan Lincoln menyebutkan bahwa penelitian kualitatif mencakup penggunaan dan pengumpulan beragam material empiris yang digunakan - studi kasus, pengalaman personal, instrospektif, kisah hidup, teks wawancara, observasi, sejarah, interraksional, dan teks visual yang mendeskripsikan momenmomen rutin dan problematik serta makna dalam kehidupan individual.

Sumber data dalam penelitian ini adalah tulisan dalam buku dengan judul "Upacara Adat Pernikahan Dayak Tobag” diterbitkan oleh Dinas Pendidikan dan Kebudayaan, Kabupaten Sanggau. Adapun data yang digunakan yaitu hukum adat pranikah, menikah, dan hukum adat pascapernikahan dalam tradisi Dayak Tobag. Teknik analisis data dilakukan dengan cara menelaah dan mendeskripsikan secara detail ungkapan yang terkadung dalam data tersebut. Teknik ini bertujuan 
mengungkap fakta, keadaan, fenomena, dan keadaan yang terjadi tentang adatistiadat dalam Dayak Tobag yang ditulis oleh pegarang Arianto dan D. Dulanang Yones serta ditafsirkan oleh peneliti apa adanya. Terkait data dan analisis data, Patton (Moleong dalam Faisal, 2018: 35) menjelaskan bahwa teknik analisis data adalah suatu proses untuk mengatur urutan data, mengorganisasikannya ke dalam suatu pola, kategori, dan satuan uraian dasar. Teknik analisis data berfungsi mengelompokkan data yang serupa berdasarkan fokus penelitian tentang istilah dan pemaknaan dalam adat pernikahan Dayak Tobag, Kabupaten Sanggau, Kalimantan Barat .

\section{PEMBAHASAN}

Istilah bahasa yang digunakan dalam adat pernikahan Dayak Tobag bermacam-macam. Pemilihan bahasa yang unik dalam tradisi tersebut sangat kental terlihat. Kekayaan istilah-istilah yang digunakan syarat dengan nilai-nilai dan pemaknaan di dalamnya. Berikut dipaparkan penggunaan kata dan istilah dalam adat pernikahan Dayak Tobag, Kabupaten Sanggau, Provinsi Kalimantan Barat.

\section{Jenjang Pranikah}

Dalam tradisi pernikahan masyarakat Dayak Tobag di Kabupaten Sanggau, tahapan prosesi yang harus dilakukan pada jenjang pranikah, yaitu sebagai berikut.

\section{Pado'k}

Pado'k merupakan istilah yang digunakan dalam Dayak Tobag untuk menyatakan 'perjodohan'. Pado'k atau perjodohan ini sudah dilakukan sejak zaman dahulu kala, yaitu sejak ada masyarakat di daerah tersebut sampai zaman kolonial Belanda. Tradisi perjodohan ini pun dilakukan oleh beberapa kelompok atau keluarga secara turun-temurun di kalangan masyarakat adat Dayak Tobag sampai saat ini (Arianto \& D.Dulanang Yones: 2011). Pada masa pegaruh agama Hindu, pado'k 'perjodohan' menjadi tradisi sampai masa pemerintahan Raja Gagok di Kerajaan Tayan. Tradisi ini pun berlanjut pada masa pengaruh Islam terutama di lingkungan keraton atau istana kerajaan. Khusus perjodohan yang dilakukan oleh Dayak Tobag berada di Keraton Tayan, yaitu perjodohan anak raja Tayan dengan anak raja kerajaan lain (bangsawan). Contoh Putri Periyok dari kerajaan Tayan dengan Raden Likar dari kerajaan Tanjungpura.

Tujuan dilakukan tradisi pado'k (perjodohan) atau memado' $k$ (menjodohkan) adalah salah satu keluarga yang masih lajang dengan salah seorang dari kerabat lain untuk calon pasangan hidupnya. Kedua orang tersebut sudah terikat secara batin, meskipun belum seutuhnya. Perjodohan dalam tradisi Dayak Tobag hanya memerlukan waktu kurang lebih tiga bulan setelah adanya kesepakatan kedua belah pihak orang tua mereka. Hal ini untuk menghindari adanya hubungan yang tidak diinginkan yang bisa melanggar ketentuan adat yang berlaku. Pado'k (perjodohan) ini dilakukan oleh orang tua calon pasangan. Tradisi tersebut tentu saja memiliki kelemahan bahwa calon pasangan pengantin belum mengenal pribadi satu sama lainnya. 
Tuah Talino

Tahun XIV Volume 14 Nomor 1 Edisi 31 Juli 2020

ISSN 0216-079X E-ISSN 2685-3043

Balai Bahasa Kalimantan Barat

\section{Sanggan Bebayo'}

Rangkaian tradisi adat berikutnya sanggan bebayo' yang bermakna 'masa pacaran'. Sanggan bebayo' istilah yang digunakan sangat identik di kalangan remaja masa kini. Tradisi ini sudah dilakukan oleh beberapa kalangan masyarakat adat Dayak Tobag di era-kerajaan Hulu Aik Kuno. Hal tersebut dibuktikan dalam cerita legenda Dayang Geliat yang mengisahkan pahit getirnya hidup mencari pasangan dan menjalaninya. Legenda Dayang Jejumpa'k Jelumpang dan Jelumpai mengisahkan kehidupan keserakahan dan kesombongan demi mencari pasangan, hancur oleh cinta kasih sayang ibundanya. Kemudaian legenda Dayang Bungsu dan Buah Bunut yang menceritakan ketamakan persaingan yang dihancurkan ketulusan dan kasih sayang. Serta, legenda Dayang Senandi yang menceritakan keangkuhan yang dihancurkan penantian cinta yang tulus. Cerita-cerita legenda tersebut dulunya sangat kental dalam masyarakat adat Dayak Tobag. Adanya legenda ini menjadi cermin bagi kalangan muda-mudi Dayak Tobag.

Bebayo' atau pacaran sebagai rentang waktu untuk mengenal satu sama lainnya. Dalam masa tersebut tentu komunikasi sangat diperlukan. Pengenalan pribadi dalam satu pasangan sangat diperlukan supaya tidak ada lagi kata salah pilih pasangan setelah menikah. Bercermin dari legenda di atas diharapkan setiap muda-mudi selama pacaran tidak melanggar hukum adat yang berlaku. Bebayo' 'pacaran' adalah kemauan sendiri dari seorang gadis atau seorang bujangan. Pada jaman Pateh Batu Antik ada istilah dalam adat yang berbunyi bebayo' bekendak. Makna dari bebayo' bekendak yaitu berpacaran memang sudah kemauan. Artinya, ketika pasangan muda-mudi ini mendapat masalah dalam berpacaran, tidak bisa menyalahkan orang lain.

\section{Tonya' Menonya'}

Tonya' Menonya' atau melamar menjadi bagian dari prosesi pranikah dikalangan manapun di Indonesia. Masyarakat di nusantara khususnya Kabupaten Sanggau menganut sistem tonya' menonya'. Terkait tradisi tonya' menonya', Martina pernah menulis dan terbit dalam Inside Pontianak tanggal 26 Januari 2020 https://insidepontianak.com/2020/01/26/tradisi-tonya-menonya-dayaktobag/. Dalam masyarakat Dayak Tobag, kisah Dayang Unge dan Bujang Bokor juga ada proses melamar, meskipun proses itu digagalkan kedua belah pihak keluarga karena pasangan masih ada pertalian darah. Begitu juga pada legenda Dayang Senandi ada proses melamar yang dilakukan putra bungsu Raja Hulu Aik. Tradisi melamar ini sudah lama dilakukan dan sampai saat ini pun masih berlaku meskipun dengan cara yang berbeda setiap sukunya.

Dalam tradisi adat Dayak Tobag, tonya' menonya' 'melamar' dilakukan oleh seorang perantara. Perantara itu di sebut Ma'Inang untuk laki-laki dan Ino' Inang untuk perempuan. $M a^{\prime}$ atau Ino' inang sebagai seorang perantara itu harus orang yang sudah berkeluarga atau pernah berkeluarga. $M a^{\prime}$ atau Ino' inang sangat memegang cendaga adat 2 (dua) real. Peranan $M a$ ' atau Ino' inang sangat menentukan jadi tidaknya suatu calon pasangan menuju ke jenjang pernikahan. Dalam melakukan lamaran, $M a^{\prime}$ ' atau Ino' inang berhati-hati agar tidak salah basa sungu 'bertutur kata'. Apabila salah bertutur kata, akan batal prosesi ke depannya.

Prosesi melamar ini dilakukan pihak laki-laki kepada pihak perempuan dan harus mengacu kepada ketentuan adat tonya' menonya' sebagai berikut. a) 
Pertama, menyuguhkan topok atau tempat kapur sirih lengkap (kapur, sirih, gambir, pinang, tembakau, minyak pa'kbale, kacup). b) Kedua, Ma' atau Ino' inang ini biasanya memulai dengan salam. Selanjutnya, berbasa-basi secara singkat barulah menyatakan maksud kedatangannya ke lawing/lawak 'rumah'. Biasanya dialog singkat dilakukan oleh $\mathrm{Ma}$ ' atau Ino' inang seperti ' $\mathrm{Ka}$ lawak to' ku ngringang ada utat manu igong. Ope utat ya dah di uku' ke urag lain kah nggi mbun. Aku to' mae' ajad sanu ausnye da'k mensiak ngorang utat pengorak manu igong kita' ya." Makna dari pengantar atau basa-basi dari $\mathrm{Ma}^{\prime}$ atau Ino inang yaitu dikeluarga ini saya mendengar ada memiliki hutan rimba yang belum dijamah manusia. Apakah hutan tersebut sudah ada yang memilikinya? Saya membawa maksud baik, Saudara ini yang ingin berladang dan bercocok tanam di tanah tuan itu). c) Simbol perempuan gadis atau perawan diganti dengan istilah utat pengorak manu igong 'hutan rimba yang belum dijamah manusia'. d) Simbol perempuan janda diganti dengan istilah utat terada/ babas terada 'hutan pernah digarap atau dikelola /bekas ladang'. e) $M a^{\prime}$ ' atau Ino 'inang tidak boleh langsung mengutarakan maksud, hal ini dianggap kurang baik dalam aturan komunikasi. f) Tuan rumah yang didatangi harus menjawab, bila itu menerima lamaran. Contoh jawaban yang diberikan oleh tuan rumah "ao' ng kemana'g ada utat penorak manu igong. Nggi unyump boh nang nguku'nyeh.... Dah kemana'g pakat mau' diorangnyeh." Makna yang terkandung di dalam pesan di atas yaitu ya, kami memiliki hutan rimba yang belum dijamah manusia. Masih belum ada yang memilikinya... Dan kami sudah bersepakat dan setuju untuk melimpahkannya kepada saudara yang dimaksud tuan. g) Bila tuan rumah menolak lamaran itu, mereka akan menjawab seperti berikut. “ao' ng. kemana'g ada utat pengorak manu igong. Sayangnyeh utat nang di kemau' kita ya dah kemana'g bori ken ang lain." Artinya ya, kami memiliki hutan rimba yang belum dijamah manusia yang seperti tuan katakan. Sungguh disayangkan, hutan yang dimaksud tuan rencana kami hibahkan ke orang lain atau sudah ada empunya.

Dalam cerita legenda Dayak Tobag, kisah yang tidak mengalami masa pacaran (senggan bebayo') di jaman raja-raja adalah legenda Dayang Nage'k 'legenda Dara Nante/i'. Kisah cinta pasangan tanpa masa pacaran ini menjadi legenda hidup sampai kini masih terus dihormati masyarakat adat di tanah Labai dalam upacara adat munjong kampong. Kisah yang mengharukan ketika tiba-tiba mengandung tanpa tahu siapa suaminya. Dalam penantian dan perjalanan panjangnya dengan penuh ketulusan cinta dan kesetiaan, akhirnya bertemu dengan jodoh sejatinya itu.

\section{Betunang}

Rangkaian acara berikutnya adalah adat betunang atau adat pertunangan. Ma' atau Ino inang sebagai perantara menjadi tokoh penting dalam mensukseskan acara betunang atau pertunangan ini biasanya diadakan pada malam hari atau setengah hari petang. Pada zaman raja-raja dulu, hanya ada pengaruh Hindu Kaharingan. Adat pertunangan sangat sederhana yaitu setelah proses melamar diterima keluaga sang gadis. Melamar cukup hanya membawa barang yaitu topok 'tempat kapur sirih' isi lengkap saja. Jika ada barang lainnya, hanya sebagai hadiah buat sang gadis seperti bokor 'tempat penyimpanan perhiasan/rambut', tetapi barang itu tidak wajib karena hanya orang bangsawan dan keturunan raja 
Tuah Talino

Tahun XIV Volume 14 Nomor 1 Edisi 31 Juli 2020

ISSN 0216-079X E-ISSN 2685-3043

Balai Bahasa Kalimantan Barat

saja yang memilikinya. Topok dan bokar merupakan simbol yang digunakan oleh masyarakat Dayak Tobag bahwasannya setiap keluarga laki-laki (pelamar) harus siap dengan prasarat yang ditetapkan oleh keluarga calon istrinya. Tapor 'tempat kapur sirih yang berisi lengkap' menandakan bahwa pihak laki-laki untuk masuk ke keluarga calon istrinya harus memenuhi permintaan atau keinginan yang ditetapkan dan dianggap sakral dalam masyarakatnya. Sedangkan bokar 'tempat penyimpanan perhiasan' yang memiliki makna pada saat hari $\mathrm{H}$ atau pernikahan mereka nanti diwajibkan mengisi wadah itu dengan perhiasan. Oleh karena itu, tapor menjadi tidak wajib ada dalam tradisi betunang Dayak Tobag.

Perubahan beberapa istilah dalam Dayak Tobag terjadi ketika ada pengaruh agama Islam. Pengaruh Islam merubah istilah betunang dengan sebutan ngantar barang. Dari Namanya, ngantar barang tentu saja ada barang-barang antaran buat sang gadis. Barang-barang itu sebagai tanda pinangan dari bujang untuk sang dara. Seiring perkembangan zaman, pengaruh agama Katolik dan Kristen Protestan mengubah istilah ngantar barang menjadi tukar cincin. Dalam pertunangan tukar cincin tersebut, harus mengikuti ketentuan sebagai berikut. a) Barang kelengkapan yang harus dipersiapkan seperti cincin dua botok'k, sapu tangan, barang lain yang merupakan tambahan berupa baju rok satu stel, kain sarung, dan handuk, serta perlengkapan hias dan mandi. b) Apabila tidak ada barang bawaan lainnya seperti di atas, harus membawa sapu tangan yang dilipat gede saja. Gede dalam bahasa Indonesia bermakna 'gadai'. Dalam hal ini, sapu tangan dilipat bukan sertamerta maknanya hanya menggadaikan sapu tangan. Makna sebenarnya adalah hanya sapu tangan yang diberi kreasi seni lipatan saja sebagai pemberian tulus karena hanya itu kemampuan dari mempelai laki-laki.

\section{Kebabar}

Kebabar adalah upaya menghalangi terjadinya tindakan asusila pasangan yang sedang berpacaran. Tindakan ini sifat memaksa pasangan yang sedang pacaran untuk menikah karena dikhawatirkan terjadi hal-hal yang tidak diinginkan. Ketentuan adat seperti ini memang ada yang mengatur meskipun bertentangan dengan hak asasi seseorang dan tradisi agama. Namun, ketentuan ini tetap berlaku dan mengikat karena memiliki tujuan yang baik. Seseorang menentukan kebabar tidaklah sembarangan atau semaunya saja. Ada ketentuanketentuan yang dirumuskan dalam hukum adat Dayak Tobag. Pasangan yang bisa dikebabar apabila sering pacaran di tempat-tempat gelap atau tempat sunyi; sering di rumah ketika orang tuanya tidak ada di rumah; sering pacaran sembunyisembunyi tanpa sepengetahuan salah satu orang tuanya; dan pacaran tidak mengenal waktu.

Dengan aturan tersebut, sebenarnya orang tua zaman dulu tidak menginginkan adanya kawin paksa atau kebabar. Saat ini, perilaku dan tindakan muda-mudi yang lewat batas atau etika moralnya melanggar aturan yang ada maka para tokoh masyarakat melakukan hal tersebut. Bila pasangan ini ada pantangan dalam pertalian darah, akan dikenakan juga hukuman yang tertuang dalam adat bemale'. Prosesi kebabar sesuai dengan adat kebabar. Mereka yang dikebabar dikenakan satu real dedeng sebagai penebus kesalahan dan selanjutnya paling lama 3 hari masa mengumpulkan keluarga kerabat keduanya. Kemudian, 
Tuah Talino

Tahun XIV Volume 14 Nomor 1 Edisi 31 Juli 2020

ISSN 0216-079X E-ISSN 2685-3043

Balai Bahasa Kalimantan Barat

mereka dinikahkan menurut ketentuan adat dan tingkat pernikahan pilihan mereka.

\section{Pernikahan}

Pada zaman dulu, masalah pernikahan dan biaya ditanggung oleh pihak yang meminta atau bele'k nerima'. Pihak tama' bele' $k$ atau mengikuti keluarga yang meminta, hanya membawa bokal pemae' 'barang bawaan' agar tidak dianggap nongkok atau menumpang dalam istilah adatnya. Saat ini, kedua belah pihak sudah saling mengerti tanggung jawab penyelenggaraan upacara adat pernikahan. Sesudah waktu yang telah ditentukan dalam pertunangan, kedua belah pihak akan selalu bepaham 'bermusyawarah' untuk persiapan dan mensukseskan upacara pernikahan. Masa persiapan untuk pernikahan disebut besadak. Dalam masyarakat Dayak Tobag, upacara adat pernikahan dibagi beberapa tingkatan yaitu sebagai berikut.

\section{a. Upacara Adat Beloki Bebini Mbio Lopas Atau Mbir Lopas}

Dalam adat pernikahan Dayak Tobag tidak menekan dan memaksa masyarakatnya harus melaksanakan adat pernikahan penuh seperti yang diharapkan. Bagi yang kurang mampu atau untuk kalangan kurang mampu, adat beloki bebini mbio lopas/mbir lopas atau adat pernikahan sangat sederhana atau adat pernikahan di bawah tangan (nikah sirih dalam agama Islam).

Adat ini tergolong sangat ringan karena hanya bermodalkan seekor ayam kurang lebih setengah kilo gram. Setelah imam ritual atau tukang pipis memberkati kedua mempelai, allu bulu sayap dan bulu ekor dicabut, ayamnya dilepas, bulu ayam tadi dibakar dan nyecel (cempale istilah Melayu yang bermakna bersyukur meskipun tidak menyantap hidangannya). Dalam upacara adat ini tidak boleh menyebut nama Jebata Pejaji Penampa' atau Tuhan Pencipta karena tidak ada hewan kurban dalam upacara tersebut.

Konsekuensi dari upacara adat beloki bebini mbio lopas atau mbir lopas harus mengikuti aturan yang sudah ditentukan sebagai berikut. Ketentuan itu yaitu anak yang dilahirkan tidak bisa diberkati dalam upacara adat nonong torat; mempelai tidak bisa menuntut adat 7 real dan di atasnya; kedua mempelai tidak bisa menuntut adat mas 7; bila tidak memberitahu pernikahan ini kepada pengurus adat/pengurus kampung/dan kaum kerabat dekat akan dikenakan adat pelinsam; dan pernikahan ini dianggap pernikahan gantung, bila ada kemampuan harus berlanjut pada adat pernikahan sederhana.

\section{b. Upacara Adat Beloki Bebini Bepipis Becale'k Abis Man Manu'k}

Upacara adat beloki bebini bepipis becale'k abis man manu'k atau adat pernikahan sederhana. Pernikahan dengan upacara adat ini yang sering dilakukan masyarakat kurang mampu atau miskin. Adat pernikahan ini tidak mengantung dan mempunyai kekuatan hukum adat tetap dan mengikat.

Upacara adat ini menggunakan dua orang tukang pipis atau imam ritual dan ayam yang digunakan sebagai hewan kurban nama jebata pejaji penampa' harus disanjung dan disebut dalam upacara ini. Dalam upacara ini juga menggunakan petepara atau hidangan untuk umang lawing 'orang yang hadir'. Minimal hidangan hewan kurban untuk ritual adat besasi sederhana tidak melibatkan semua tokoh adat dan agama. Silah' adalah bukti bagian paha sampai ceker dari 
hewan kurban diserahkan kepada tukang pipis, pengurus, dan wakil kerabat kedua belah pihak. Urutan ritual hampir sama dengan upacara pernikahan penuh.

\section{c. Upacara Adat Beloki Bebini Ponoh}

Pernikahan dengan upacara adat beloki bebini ponoh sering digunakan oleh masyarakat adat dan tentu memiliki kekuatan hukum adat tetap serta mengikat. Upacara adat ini menggunakan dua orang tukang pipis atau imam ritual. Ayam dan babi digunakan sebagai hewan kurban. Ayam jantan (jago) untuk kurban sebanyak 2 (dua) ekor, babi 1 ekor minimal $15 \mathrm{~kg}$ dan maksimal $40 \mathrm{~kg}$. Nama jebata pejaji penampa' harus disanjung dan disebut dalam upacara tersebut. Dalam upacara ini juga menggunakan petepara 'hidangan' untuk umang lawing 'para yang hadir'. Hidangannya pun harus hidangan khusus dan dalam upacara adat ini tidak boleh sembarangan. Hidangan seperti ayam dicampur buah pisang atau labu kuning (perenggi), babi campur buah cempedak atau nangka. Untuk hidangan, jumlahnya disesuaikan kebutuhan. Intinya jangan sampai kekurangan makanan saja pada saat upacara.

Makna petepara 'hidangan' dalam pernikahan Dayak Tobag memiliki nilai kearifan lokal yang tinggi. Buah pisang melambangkan keturunan dan persatuan keluarga; buah perenggi atau labu kuning melambangkan kematangan dan berkembang maju; buah cempedak atau nangka melambangkan banyak manfaat positif, ikatan, dan kemakmuran dalam suatu keluarga; dan pantangan umbut untuk hidangan karena menyimbolkan kemusnahan dan kematian. Acara pernikahan ini harus dihadiri minimal satu orang yang mewakili unsur sebagai berikut. Pertama, domong adat kedua belah pihak. Kedua, pengurus adat (seperti temenggung, jaya atau pesirah). Ketiga, kerabat yang menikah dari kedua belah pihak. Keempat, ma' atau ino inang. Kelima, orang di luar keluarga yang menjadi saksi. Keenam, tokoh agama atau pemimpin umat. Mereka ini turut serta bertutur kata dalam ritual adat basasi.

Ritual adat dalam upacara pernikahan penuh dapat dikelompokkan untuk Tuhan, manusia, dan hewan. Ritual kepad Tuhan ditunjukkan yaitu, 1) ngansor topok dan nyirak 'penyerahan kepada Tuhan dan permohonan perlindungan'. 2) bepipis becale' $k$ bepetula 'pemberkatan tanda perjanjian dan doa' di pagi hari puncak; dan 3) besasi 'maklumat janji pernikahan dengan pengukuhan hukum adat' sebagai ritual penutup. Ritual untuk penghormatan kepada tamu, yaitu 1) nyamunt temue 'penyambutan tamu', 2) betumu bepaham malap 'pertemuan dan musyawarah keluarga kedua belah pihak' pada malam puncak. Terakhir, ritual hewan kurban dalam adat basasi dalam masyarakat Tobag melibatkan semua tokoh. Ritual tersebut misalnya sila' 'bukti bagian paha sampai ujung ceker atau kaki' dan bau' 'bagian lengan' dari hewan kurban diserahkan kepada tukang pipis, pengurus, dan wakil kerabat kedua belah pihak. Khusus untuk $m a$ ' atau no' inang diberi lutek kongkong 'bagian bawah leher babi kurban'. Orang-orang yang bertugas mengurus hewan kurban dari mencari sampai membunuh dan dihidangkan diberi lutek sengabai (kulit sampai daging bagian belakang babi kurban dipotong memanjang dua bagian kiri dan kanan dari pangkal leher sampai batas buntut selebar tiga jari). Selanjutnya, dilakukan pancang adat atau pengikat adat. 
Tuah Talino

Tahun XIV Volume 14 Nomor 1 Edisi 31 Juli 2020

ISSN 0216-079X E-ISSN 2685-3043

Balai Bahasa Kalimantan Barat

\section{d. Upacara Gawai Adat Beloki Bebini}

Upacara gawai adat beloki bebini adalah upacara pesta besar pernikahan masyarakat adat Dayak Tobag. Pada awalnya dibuat ritual ngansor topok dan nyirak barulah ritual selanjutnya bengondang parang yang dilanjutkan dengan segala kegiatan lain berupa hiburan dan persiapan menuju puncak ritual pernikahan pada hari ke tujuh. Kegiatan hari ketujuh atau hari puncak adalah ritual bepipis becale'k betula. Dalam bepipis, harus menggunakan ayam jantan kurban 2 ekor dan babi kurban minimal seberat $40 \mathrm{Kg}$. Setelah matahari menyingsing turun (setelah tengah hari sekitar jam 12.30an waktu setempat) dilakukan ritual ngumpan olo' tanga 'memberkati tangga penyambut tamu'. Puncak acara adalah ritual adat besasi atau berjanji semaya.

Persiapan untuk petepara adalah babi sebanyak 7 ekor masing-masing minimal seberat $40 \mathrm{Kg}$. Ayam sesuai kebutuhan saja atau hanya bila ada tamu yang tidak bisa makan babi. Petepara tidak boleh dari umbut karena akan menghilangkan kesakralan upacara adat pernikahan itu. Hidangan untuk para kerabat dan tamu tidak hanya lauk-pauk. Selama hari kedua sampai hari keenam, dibuat kegiatan awalnya menumbuk beras biasa dan beras ketan, mengupas kelapa, mengupas buah perenggi buah ubi jalar untuk bahan membuat dodol, memasak tumpi' 'kue', memasak semanan, memasak pansoh, dan memasak dodol. Hiburan pada zaman pengaruh kerajaan Majapahit berupa tarian ma'iyong, lain-lain seperti bejonggan, bepantun, dan bedendo atau bernyanyi. Di masa modern ini, hiburan bisa disesuaikan asal tidak bertentangan dengan aturan adat dan aturan pemerintah. Hiburan ini selama 5 hari mulai hari kedua sampai hari keenam.

Pada hari keenam dilakukan ritual perarakan penyambutan mempelai oleh 7 penari yang disebut dayang pelayan putri dengan iringan musik tradisional. Mempelai yang disambut kerabat pasangannya di muka lawing 'depan pintu masuk'. Pada malam ketujuh, semua kerabat kedua belah pihak berkumpul dan diperkenalkan agar terjadi keakraban diantara kedua pihak. Penyampaian prosesi ritual adat bapipis dan besasi (pemberkatan dan peneguhan adat nikah) pada hari ketujuh dari pagi sampai sore. Ritual adat besasi adalah akhir ritual adat pernikahan masyarakat Dayak Tobag.

\section{Hukum Adat Pascapernikahan}

Hukum adat setelah pernikahan juga diuraikan oleh pengurus adat dalam ritual adat besasi. Penetapan hukum adat ini sebagai pancang 'peneguh' dan sebagai rambu peringatan bagi seseorang yang sudah bersuami/istri. Hukum adat tujuan awal nya untuk membuat jera agar pelaku insaf bahwa hukuman merupakan tindakan akhir bila pelaku tidak jera.

Dalam tradisi Kristiani, Gereja mempunyai sanksi atau hukuman bila pasangan suami istri bercerai hidup. Hukumannya tidak boleh menikah menurut tradisi Gereja kedua kali dan pernikahan berikutnya. Meskipun dalam tradisi muslim menikah lebih dari satu kali diizinkan, hal itu tentu menurut ketentuan Islam. Masyarakat adat Dayak Tobag tidak menginginkan adanya perceraian dalam pasangan suami istri yang sudah diresmikan dan diberkati menurut adat. Untuk mencegah perceraian terjadi, para leluhur terdahulu bersepakat menyusun ketentuan hukum adat yang berkenaan dengan hal ini. Hukum adat itu diantaranya 
sebagai berikut, hukum adat prapernikahan atau sebelum pernikahan adalah hukum adat untuk pelurusan masalah, pembersihan, permohonan ampun dan maaf. Hal ini dilakukan untuk menjaga hal-hal yang tidak diinginkan dari akibat seperti tindakan pelanggaran ketentuan kampung, pencabulan dan pertalian darah. Para leluhur orang Dayak Tobag membuat ketentuan hukum adat sebagai berikut.

\section{a. Adat Masalah Pergaulan dan Komunikasi}

Adat masalah pergaulan dan komunikasi merupakan salah satu penjaga atau yang menjadi perisai pergaulan dalam masyarakat adat Dayak Tobag. Adat ini bertujuan untuk memperbaiki dan meluruskan sesuatu yang keliru menurut pengelihatan atau pandangan seseorang dalam kehidupan masyarakat dengan masalah etika, moral, dan asusila. Pasangan baru suami istri harus diingatkan tentang masalah pergaulan dan berkomunikasi dengan saudara, kerabat, sahabat, dan kenalannya, karena erat kaitannya untuk menjaga keharmonisan hubungan dengan pasangan.

Jenis masalah pergaulan dan komunikasi dalam upacara adat pernikahan ini meliputi adat timpak kemata labat ka oti, adat nganggoh, adat betama'k kediri', adat nggagap, adat nyangka ntalak, adat siku' tekesalah, adat penyangkah pelangor sumpit, adat ntulah, dan adat berutak bekampak. Kesembilan istilah adat pergaulan dan komunikasi yang digunakan oleh masyarakat Dayak Tobag memiliki keunikan tersendiri. Berikut dipaparkan istilah-istilah dalam tradisi adat tersebut.

\section{Adat Timpak Kemata Labat Ka oti}

Adat timpak kemata labat $k a$ oti ini memiliki makna bila ada salah pandangan atau tampak kurang baik dipandang mata dan kemungkinan ada maksud tersembunyi dalam hatinya. Hal ini bukan saja berlaku bagi pasangan pengantin baru tapi juga pasangan yang sudah lama membina rumah tangga. Seseorang kena adat timpak kemata labat ka oti ini apabila sebagai berikut. 1) Seorang laki-laki yang tampak berdua dengan gadis/janda tapi tidak ada orang lain di rumah itu. 2) Seorang laki-laki yang tampak berdua dengan gadis/janda berjalan-jalan tanpa tahu arah tujuannya sampai petang baru kembali. 3) Seorang laki-laki yang tampak berdua dengan gadis/janda berjalan belanja dari pagi sampai malam baru pulang. 4) Seorang laki-laki yang tampak mengintip gadis/janda atau sebaliknya. 5) Seorang laki-laki memberikan tanda (berupa isyarat seperti bunyi atau tanda lain) kepada seorang gadis/janda dan sebaliknya. 6) Seorang laki-laki yang berjalan bersiul-siul di kebun/ladang/tempat kerja yang ada orangnya dan sebaliknya. 7) Kejadian-kejadian serupa tersebut, dimaksudkan prasangka dan praduga ada pelanggaran etika dan pelecehan asusila.

Sesorang yang melakukan pelanggaran atau kesalahan dikenakan adat empat real dedeng 'berdiri sendiri' dan dipancang adat. Pancang adat adalah ketetapan dan sanksi adat untuk antisipasi tindakan kedepannya. Adat ini bagi seorang yang sudah berkeluarga sebagai pengingat agar menjaga komunikasi jangan sampai terlalu intim, dalam hal ini menjaga batasannya.

\section{Adat Nganggoh}

Adat nganggoh memiliki makna 'ada maksud dan keinginan berbuat tapi belum dengan tindakan fisik'. Adat ini dikenakan apabila salah satu mengakui kalau mereka telah berhubungan suami istri, tetapi setelah diperiksa kepada 
Tuah Talino

Tahun XIV Volume 14 Nomor 1 Edisi 31 Juli 2020

ISSN 0216-079X E-ISSN 2685-3043

Balai Bahasa Kalimantan Barat

pasangan yang dimaksud tidak terjadi apa-apa. Hal tersebut tidak ada tindakan amoral seperti yang telah dijelaskan di atas. Seseorang yang dinyatakan terkena adat empat real dedeng, lelaki yang membayar adat ke perempuan dan disebut bala'k ngamang, perempuannya disebut puke' nampet. Menurut adat, itu hanya khayalan saja dan hanya berupa pelecehan melalui kata-kata saja serta dipancang adat. Meskipun hukumannya agak ringan, hal ini sangat ditekankan kepada pasangan suami istri.

\section{Adat Betama'k Kediri'}

Adat betama'k kediri' ini dimaksudkan adanya kehendak hati yang kuat untuk memiliki seseorang yang jadi pujaan hati, tetapi cintanya tak diterima atau dengan kata lain 'cinta bertepuk sebelah tangan' sehingga melakukan tindakan dan perbuatan yang tidak mengenakkan pasangan yang dimaksud. Jadi, adat ini dikenakan apabila seseorang datang menemui gadis/janda atau sebalik nya, yang bersangkutan tidak menerima dan menolak yang bersangkutan. Bila berbuat sekali yang bersangkutan dikenakan empat real dedeng saja, dan apabila mengulangi lagi maka yang bersangkutan dikenakan empat real dengan satu ekor babi seberat 20 (dua puluh) $\mathrm{Kg}$ dan dipancang adat.

\section{Adat Nggagap}

Adat Nggagap ini dimaksudkan adanya niat karena nafsu birahi yang tak tertahan sehingga berani melakukan tindakan menemui atau mendatangi lawan jenisnya. Adat ini berlaku apabila seorang laki-laki mendatangi dan menemani tidur seorang gadis/janda/perempuan ada pasangan atau sebaliknya. Hal ini setelah ditanya secara terpisah kedua belah pihak, ternyata belum melakukan perbuatan asusila atau hubungan suami istri.

Yang bersangkutan hanya dikenakan empat real dedeng saja. Apabila sudah melakukan tindakan amoral, asusila atau sudah berhubungan suami istri akan dikenakan empat real dengan satu ekor babi seberat 20 (dua puluh) kg atau adat penyombe' atau pengotor kampong. Jika ada pantangan silsilah darah, akan dikenakan adat bemale'. Jika yang bersangkutan masing-masing masih lajang akan dikebabar atau langsung dinikahkan. Lelaki yang sudah beristri, si gadis atau si janda harus membayar adat mas tujuh atau sebaliknya. Bila tidak menikah, akan dihukum adat pelanggaran yang disebut adat pengegoh kampong dan dipancang adat.

\section{b. Adat Mas Tujuh}

Adat mas tujuh ini mengatur etika pergaulan, moral, dan asusila. Adat ini adalah adat penjaga dan pendamai dalam rumah tangga. Itu berarti sebagai pasangan suami istri harus menghormati pasangan dan menjaga keharmonisan rumah tangga. Apabila ada tindakan amoral dan asusila yang membuat salah satu pasangan tersakiti batinnya, adat ini berjalan.

Asal usul sejarah adat mas tujuh adalah adat berupa emas tujuh gram saja dan tidak ada yang lainnya. Maka dari nilai emas dibarter untuk memenuhi dan menyiapkan barang untuk keperluan ritual adatnya. Setelah zaman kerajaan, sekitar abad ke-15 sangat sulit untuk mendapatkan atau mengadakan emas, hanya kalangan bangsawan dan kaum kerajaan yang mampu. Maka Pateh (Adipati) penguasa Benua Adat dan para Tetua Adat leluhur Dayak Tobag tempo dulu memperbaharui adat mas tujuh bukan lagi berupa emas tujuh gram, akan tetapi 
Tuah Talino

Tahun XIV Volume 14 Nomor 1 Edisi 31 Juli 2020

ISSN 0216-079X E-ISSN 2685-3043

Balai Bahasa Kalimantan Barat

berupa Ringgit (zaman kerajaan Islam dirubah menjadi real jampal, seekor babi dan perlengkapan ritual adat.

Ketentuan adat mas tujuh dijelaskan sebagai berikut. Pertama, harus disiapkan seekor babi seberat dua puluh (20) $\mathrm{Kg}$ dan perlengkapan petepara 'bahan masakan'. Kedua, perlengkapan ritual: real jampal untuk puawang empat real, topok, ayam jantan, dan tampong tawar; lengkap. Ketiga, apabila dia lajang (pria/wanita) tidak ada pantang keturunan/silsilah, harus membayar kepada pasangan (suami/istri) yang diselingkuhinya dan ini disebut seroma mas tujuh sebesar tujuh real. Bila ada pantangan keturunan/silsilah harus membayar tujuh setengah real lengkap seperti point di atas. Keempat, apabila istri yang selingkuh, dia harus membayar empat real dedeng kepada suaminya, dan sebaliknya; bila ada pantangan keturunan maka membayar lima setengah real; dan ini disebut siku mas tujuh atau menyikut pasangan hidupnya. Kelima, kedua pasangan dikenai adat penyombe' kampong.

\section{c. Adat Sara'k atau Masalah Penceraian}

Adat sara'k adat 'perceraian' merupakan adat yang berlaku setelah menikah. Adat sara'k hukum adat yang mengatur masalah perceraian, meskipun pada dasarnya hukum adat istiadat tidak menginginkan adanya perceraian atau perpisahan antara suami istri dalam suatu rumah tangga. Adat ini sebagai sanksi atau hukuman bila perceraian itu benar-benar terjadi. Adat ini dibagi beberapa jenis perceraian dan ketentuan sebagai berikut.

\section{Sara'k Ingka'}

Adat sara'k ingka' memiliki makna perceraian atas kehendak kedua suami istri dalam keadaan sadar dan penyelesaiannya dengan cara baik-baik serta disaksikan oleh kedua belah pihak yang bercerai. Tata cara perceraian ini diatur dalam adat Dayak Tobag sebagai berikut. Pertama, apabila mereka belum mempunyai anak, mereka harus membayar empat real dedeng, harta benda mereka dibagi dua secara adil. Kedua, apabila mereka mempunyai anak, mereka harus membayar empat real dedeng, harta benda mereka menjadi hak milik anak. Ketiga, apabila anaknya hanya satu atau lebih dari dua (berjumlah ganjil), hak asuh anak harus dimusyawarahkan dan disepakati kedua belah pihak. Keempat, apabila mempunyai anak dua atau berjumlah genap, hak asuh anak dibagi dua dengan pembagian secara musyawarah antar kedua keluarga. Kelima, apabila mengacu pada ketentuan bele' $k$, ketentuan itu tidak berlaku. Jadi yang mempunyai hak atas segalanya adalah yang mempunyai bele' $k$.

\section{Sara'k Siko'nggi Suka}

Sara'k siko'nggi suka memiliki makna ada perceraian tetapi salah satu pasangan masih tidak ingin menceraikan pasangannya. Oleh karena itu, ketentuan adat diatur sebagai berikut. Pertama, pasangan yang ingin bercerai harus membayar lima setengah real dedeng. Kedua, pasangan yang tidak ingin bercerai atau membatalkan perceraian harus membayar sembilan real pada pasangannya. Apabila tidak ada reaksi lanjut dari pasangan yang ingin bercerai, proses perceraian batal karena adat. Sebaliknya, apabila pasangannya bereaksi dengan kembali membayar sepuluh real, proses perceraian dilakukan dan pasangan pun bercerai menurut adat. Ketiga, harta benda menjadi milik pasangan yang diceraikan. Keempat, hak asuh anak menjadi milik pasangan yang diceraikan. 
Tuah Talino

Tahun XIV Volume 14 Nomor 1 Edisi 31 Juli 2020

ISSN 0216-079X E-ISSN 2685-3043

Balai Bahasa Kalimantan Barat

\section{Sara'k Timpak}

Sara' timpak memiliki makna ada nya perceraian yang didasari atas ketidaksenangan atau ketidaksanggupan atas pasangannya. Pertama, pasangan tidak melayaninya sebagai suami/istri minimal selama seminggu. Kedua, pasangan menderita sakit lumpuh. Ketiga, pasangan menderita cacat fisik mental. Keempat, pasangan menderita cacat fisik lainnya dan mandul. Berdasarkan ketentuan tersebut, pasangan yang ingin bercerai tidak mempunyai rasa iba dan rasa perikemanusian lagi. Dalam adat Dayak Toba diatur sebagai berikut. Pertama, apabila pasangan tidak melayani sebagai suami/istri, pengurus adat dan orang tua akan menasehatinya dulu. Bila tidak diikuti nasihat pengurus adat dan orang tua, proses perceraian bisa dilakukan dengan membayar sepuluh real, harta benda, dan hak asuh anak menjadi milik yang menceraikannya. Apabila anak sudah dewasa, harta menjadi milik anak mereka.

Proses perceraian bisa dilakukan dengan membayar sepuluh real, harta benda menjadi hak milik pasangan yang dicerai dengan catatan kondisi pasangannya lumpuh dan cacat mental. Hak asuh anak menjadi milik yang menceraikannya. Bila anaknya sudah dewasa, harta menjadi milik anak mereka dan wajib merawat orang tuanya yang sakit. Jika kondisi pasangannya cacat fisik lainnya, proses perceraian bisa dilakukan dengan membayar sepuluh real, harta benda dan hak asuh anak menjadi hak milik pasangan yang diceraikan. Apabila anaknya sudah dewasa, harta menjadi anak-anak mereka dan wajib merawat orang tuanya yang sakit.

\section{Sara'k Rangkak}

Sara'k rangkak disebut juga adat para'k memiliki makna bila adanya penceraian didasari atas permasalahan antara keduanya yang berlarut-larut tanpa ada penyelesaian yang mengakibatkan pasangan suami-istri berpisah sekian lama. Keluarga melalui pengurus adat akhirnya memutuskan sebagai penengah dan memproses perceraian yang seharusnya sudah dikehendaki pasangan tersebut.

Masyarakat Dayak Tobag sudah mengatur penceraian itu dengan ketentuan hukum adat sebagai berikut. Pertama, proses penceraian lebih dahulu suami yang menceraikan akan menyerahkan pera'k empat. Kedua, apabila sang istri yang duluan menceraikan, ia harus menyerahkan pera'k lima. Ketiga, apabila pasangan ini belum mempunyai anak, harta bendanya dibagi dua secara adil. Keempat, apabila sudah mempunyai anak, harta bendanya akan menjadi hak milik anak mereka. Kelima, hak asuh anak bila anaknya dua atau genap, hak asuh dibagi dua. Keenam, hak asuh anak bila anaknya satu atau ganjil, akan ditentukan dalam musyawarah diantara dua pihak keluarga dengan didampingi pengurus adat. Ketujuh, bila anak dewasa, ketentuan masalah hak asuh tidak berlaku dan hal tersebut akan ditentukan oleh anak itu sendiri mau ikut bapak atau ibunya. Kedelapan, apabila mengacu pada ketentuan bele'k, ketentuan di atas tidak berlaku. Jadi, yang mempunyai hak atas segalanya adalah yang mempunyai bele'k.

\section{Nula'k Loki/Bini}

Adat nula'k loki/bini 'adat penolakan atas suami/istri'. Adat tersebut dimaksudkan adanya pasangan suami istri yang sudah terpisah rumah sejak lama tanpa tahu dasar permasalahannya. Kemungkinan lainnya, adanya ketidakmauan 
Tuah Talino

Tahun XIV Volume 14 Nomor 1 Edisi 31 Juli 2020

ISSN 0216-079X E-ISSN 2685-3043

Balai Bahasa Kalimantan Barat

salah seorang diantara mereka untuk serumah. Hal tersebut sangat dipantang dalam adat, awalnya keluarga dekat harus jadi penengah diantara keduanya agar mereka dapat rujuk kembali sebagai suami istri. Apabila tidak bisa ditengahi keluarga dekat, keluarga dekat bisa meminta pengurus adat untuk memproses mereka menurut ketentuan adat yang berlaku.

Ketentuan adat mengatur proses penceraian dalam adat ini sebagai berikut. Pertama, apabila suami yang menceraikan istrinya dengan latar belakang istrinya yang salah menurut pandangan keluarga dan pengurus adat, ia harus menyerahkan empat real dedeng. Harta benda menjadi hak milik suami. Bila ada anak, hak asuh anak menjadi milik suami. Kedua, apabila istri yang menceraikan suaminya dengan latar belakang istrinya yang salah menurut pandangan keluarga dan pengurus adat, ia harus menyerahkan empat real dedeng. Harta benda menjadi hak milik sitri. Apabila ada anak, hak asuh anak menjadi milik istri. Ketiga, apabila anaknya sudah dewasa, harta bendanya akan menjadi hak milik anaknya dan hak asuh tetap milik hak yang menceraikannya.

\section{Besait Besasat}

Adat besait besasat dilakukan sebagai pengingat agar yang melakukan perceraian tidak mengulangi yang sama. Tujuan adat tersebut mengatur proses perceraian menurut adat pera' $k$ dan menggagalkannya serta menetapkan pancang adat setelah adanya keputusan perceraian seperti yang diuraikan di atas.

Proses penyelesaian dan ketentuan adat besait besasat ini sebagai berikut. Pertama, penyerahan adat pera'k lima dan diselesaikan dengan pera'k lima. Kedua, makna lainnya adalah salah satu pasangan yang hendak menceraikan pasangan lainnya harus menyerahkan lima real dan bila tidak ada penolakan dari pasangan yang diceraikan, menurut adat pasangan itu telah syah bercerai. Ketiga, jika pasangannya menolak untuk diceraikan, yang bersangkutan yang menolak harus membalasnya dengan menyerahkan sembilan real. Kemudian, pengurus harus menetapkan ketentuan sait tunggal untuk menjaga dan mengawasai perilaku serta tindak-tanduk pasangan yang memmbatalkan perceraian. Keempat, setelah penetapan sait tunggal, pengurus adat harus memberi pengumuman kepada seluruh masyarakat (setempat). Apabila belum diumumkan sait tunggal, salah seorang pasangan yang batal bercerai megulangi kesalahan, ia harus membayar empat real. Namun, bila sait tunggal sudah diumumkan kepada seluruh masyarakat, pasangan yang mengulangi kesalahannya harus membayar enam belas real. Terakhir, bila sait tunggal juga disampaikan kepada pengurus adat di atas setingkat, pasangan yang mengulangi kesalahannya harus membayar tiga puluh dua real.

\section{d. Adat Amar}

Usaha untuk menjaga ketentraman masyarakat di wilayah kuasa adatnya, dalam hukum adat Dayak Tobag ditetapkan adat yang disebut adat amar. Adat amar merupakan adat sanksi dari pengurus adat kepada masyarakatnya yang sudah bertindak melanggar ketentuan adat dan ketentuan tambahan dalam wilayahnya. Kekuatan hukum ini tetap dan mengikat, adat amar sudah diumumkan, segenap masyarakat di wilayah adat tersebut harus menaati dan mematuhinya. Di setiap acara ritual adat besasi, pengurus adat berperan sebagai petua adat dan penasihat yang senantiasa menjelaskan pokok-pokok aturan dan 
Tuah Talino

Tahun XIV Volume 14 Nomor 1 Edisi 31 Juli 2020

ISSN 0216-079X E-ISSN 2685-3043

Balai Bahasa Kalimantan Barat

hukum adat serta wejangan kepada pasangan yang baru membangun rumah tangga. Hal ini juga harus dipatuhi pasangan suami istri. Pengurus adat amar dalam masyarakat Dayak Tobag diatur berdasarkan tingkatan dari bawah sebagai berikut.

\section{Amar Lawang Agong Adat}

Amar lawang agong adat adalah pengurus adat kuasa wilayah gang/blok/rumah betang. Kekuasaan adat ini setingkat di bawah pesirah adat dan memegang hak kuasa amar 'perintah' senilai dua real lengkap. Ketentuan adat amar ini, yaitu menyiapkan hal-hal untuk pengurusan adat di atas meliputi: seekor babi seberat sepuluh kilogram, ayam jantan satu ekor, ayam betina satu ekor, dua gantang beras biasa, dua kerek gula tebu 'gula pasir', dua cupa' $k$ tepung kopi, dua ruas bambu biasa tuak ketan, dua buah kunyit, dua buah jahe, dua buah lengkuas, dua genggam asam kandis, dua ikat daut sansang atau sengkubak dan topok lengkap.

\section{Amar Pesirah Adat}

Pesirah adat adalah pengurus adat kuasa wilayah RT/ketua RT (setingkat di bawah jaya adat) dan memegang hak kuasa amar senilai 4 real lengkap. Ketentuan adat amar pesirah ini meliputi menyiapkan hal-hal untuk mengurus adat di atas sebagai berikut: seekor babi seberat dua puluh kilogram, ayam jantan satu ekor, ayam betina satu ekor, empat gantang beras biasa, empat kerek gula tebu 'gula pasir', empat cupa'k tepung kopi, empat ruas bamboo biasa tuak ketan, empat buah kunyit, empat buah jahe, empat buah lengkuas, empat genggam asam kandis, empat ikat daut sansang atau sengkubak dan topok lengkap.

\section{Amar Jaya Adat}

Jaya adat merupakan pengurus adat kuasa wilayah dusun/RW (setingkat di bawah temenggung adat) dan memegang hak kuasa amar senilai 6 real lengkap. Ketentuan adat amar ini harus menyiapkan hal-hal untuk mengurus adat di atas sebagai berikut: seekor babi seberat tiga puluh kilogram, ayam jantan satu ekor, ayam betina satu ekor, enam gantang beras biasa, enam kerek gula tebu 'gula pasir', enam cupa'k tepung kopi, enam ruas bambu biasa tuak ketan, enam buah kunyit, enam buah jahe, enam buah lengkuas, enam genggam asam kandis, enam ikat daut sansang atau sengkubak dan topok lengkap.

\section{Amar Tumenggung Adat}

Tumenggung adat merupakan pengurus adat kuasa wilayah desa (setingkat di bawah pati adat) dan memegang hak kuasa amar senilai 8 real lengkap. Ketentuan adat amar temenggung ini harus menyiapkan hal-hal untuk mengurus adat di atas yaitu sebagai berikut: seekor babi seberat empat puluh kilogram, ayam jantan satu ekor, ayam betina satu ekor, delapan gantang beras biasa, delapan kerek gula tebu 'gula pasir', delapan cupa'k tepung kopi, delapan ruas bamboo biasa tuak ketan, delapan buah kunyit, delapan buah jahe, delapan buah lengkuas, delapan genggam asam kandis, delapan ikat daut sansang atau sengkubak dan topok lengkap.

\section{Amar Pati Adat}

Pati adat merupakan pengurus adat kuasa wilayah benua (skuasa di beberapa desa) dan memegang hak kuasa amar senilai 12 real lengkap. Ketentuan adat amar ini harus menyiapkan hal-hal untuk mengurus adat di atas yaitu sebagai 
Tuah Talino

Tahun XIV Volume 14 Nomor 1 Edisi 31 Juli 2020

ISSN 0216-079X E-ISSN 2685-3043

Balai Bahasa Kalimantan Barat

berikut: seekor babi seberat enam puluh kilogram, ayam jantan satu ekor, ayam betina satu ekor, dua belas gantang beras biasa, dua belas kerek gula tebu 'gula pasir', dua belas cupa ' $k$ tepung kopi, dua belas ruas bamboo biasa tuak ketan, dua belas buah kunyit, delapan buah jahe, dua belas buah lengkuas, dua belas genggam asam kandis, dua belas ikat daut sansang atau sengkubak dan topok lengkap.

Kegiatan adat amar pati ini dilakukan di tempat pengurus adat yang membuat amar. Sangat disarankan mematuhi amar ditingkat terendah. Misalnya, amar ketua pengurus gang/blok. Jika gang atau blok tidak ada, pengurus bawah adalah ketua RT setempat. Apabila naik ketingkat selanjutnya, akan mendapat sanksi lebih berat lagi dan jika beburusan melangkahi pengurus seharusnya, akan kena sanksi langkah lalu 'melangkahi'. Selanjutnya, apabila dimaafkan, hanya membayar 4 real dedeng dan apabila tidak dimaafkan akan dikenakan adat amar.

Ketentuan amar pati adat ini berlaku juga bagi pasangan yang baru menikah. Dalam membayar adat (semua ketentuan hukum adat) dikenakan beban untuk biaya lantat adat. Lantat adat ini memiliki makna sebagai bukti penyelesaian adat kepada pengurus adat menurut ketentuan lembaga musyawarah adat Dayak Tobag yaitu sepuluh persen dari total biaya vonis adat (biaya di luar biaya adat) dan biaya jasa orang dalam yang menyiapkan perlengkapan ritual. Penggunaan jasa orang dimaksud jika yang bersangkutan tidak sanggup menyiapkan sendiri.

\section{PENUTUP}

Berdasarkan hasil analisis dan pembahasan adat pernikahan Dayak Tobag tinjauan antropolinguistik ditemukan beberapa hal. Temuan penggunaan istilah unik dan pemaknaan yang tidak digunakan oleh tradisi etnik yang lain khususnya ketika menjelang pranikah, pernikahan, dan pascapernikahan banyak ditemukan dalam adat-istiadat Dayak Tobag. Pemilihan istilah yang unik mengandung pemaknaan yang sarat dengan kearifan lokal dalam masyarakat Dayak Tobag. Misalnya, pemilihan istilah pada jenjang pranikah, yaitu pado'k, sanggan bebayo', tonya' menonya', betunang, dan kebabar. Istilah-istilah tersebut dipakai dan ditetapkan oleh pemuka adat dengan tujuan mengatur tata cara adat menjelang pernikahan. Aturan yang telah ditetapkan itu mengikat semua lapisan masyarakat Dayak Tobag.

Pemilihan istilah atau frasa pada prosesi berikutnya juga tidak kalah uniknya, yaitu jenjang pernikahan meliputi beloki bebini mbio lopas, beloki bebini bepipis becale'k abis man manu'k, beloki bebini ponoh, dan beloki bebini. Jenjang ini merupakan proses yang menentukan bagi kedua belah pihak, baik calon kedua mempelai maupun kedua keluarga mempelai. Selanjutnya, pemilihan kata dan bahasa dalam hukum adat pascapernikahan dibagi empat bagian, yaitu adat masalah pergaulan dan komunikasi, adat mas tujuh, adat sara'k 'perceraian', dan adat amar. Penggunaan kata dan istilah terdapat pada adat masalah pergaulan dan komunikasi, yaitu adat timpak kemata labat ka oti, adat nganggoh, adat betama'k kediri, adat nggagap. Sedangkan istilah yang digunakan pada adat mas tujuh diantaranya real jampal, puawang empat real, empat real dedeng, dan adat penyombe' kampong. Pilihan diksi yang unik lainnya terdapat pada adat sara'k 
Tuah Talino

Tahun XIV Volume 14 Nomor 1 Edisi 31 Juli 2020

ISSN 0216-079X E-ISSN 2685-3043

Balai Bahasa Kalimantan Barat

'perceraian', yaitu sara'k ingka', sara'k siko'nggi suka, sara'k timpak, sara'k rangkak, nula'k loki/bini dan besait besasat. Terakhir, pilihan diksi dan bahasa pada adat amar, yaitu amar lawing agong adat, amar pesirah adat, amar jaya adat, amar temenggung adat, dan amar pati adat.

Pemilihan istilah atau frasa dalam tradisi adat pernikahan Dayak Tobag memiliki makna khusus dalam kehidupan Dayak Tobag. Keanekaragaman tersebut menunjukkan bahwa mereka memiliki khasanah lokal yang luar biasa. Tidak hanya memiliki makna khusus, kesakralan di dalamnya juga dipercaya masyarakatnya bisa mengatur kehidupan mereka lebih baik.

\section{DAFTAR PUSTAKA}

Ahmadi, Rulam. (2014). Metodologi Penelitian Kualitatif. Yogyakarta: ARRUZZ MEDIA.

Arianto dan D. Dulanang Yones. (2018). Upacara Adat Pernikahan Dayak Tobag dalam Perspektif Kebudayaan dan Agama. Sanggau: Dinas Pendidikan dan Kebudayaan Kabupaten Sanggau.

Basri, La Ode Ali. (2018). "Multikulturalisme Dalam Tradisi Lisan Orang Bajo" dalam Prosiding Kongres Internasional Bahasa Daerah Maluku. Kementerian Pendidikan dan Kebudayaan. Badan Pengembangan dan Pembinaan Bhaasa. Kantor Bahasa Maluku.

Busri, Hasan dan Moh. Badrih. (2018). Linguistik Indonesia. Malang: Madani Media.

Endraswara. https://scholar.google.co.id/scholar?q=penelitian+Endraswara+(2018:+23) $\& \mathrm{hl}=$ en\&as_sdt=0\&as_vis $=1 \&$ oi=scholart.

Faisal, Imam Agus. (2018). "Struktur, Makna, dan Fungsi Mantra Pengobatan Masyarakat Melayu Semitau Kabupaten Kapuas Hulu” dalam Jurnal Tuah Talino, Volume 12 Nomor 1, Edisi Juli 2018. https: https://ojs.badanbahasa.kemdikbud.go.id/jurnal/index.php/tuahtalino/article /view/1098

Harianah. (2015). "Telaah Linguistik dalam Cerita Rakyat Wolio sebagai Upaya Pelestarian Bahasa Daerah di Sulawesi Tenggara" diterbitkan dalam Proseding Kongres II Bahasa-Bahasa Tahun 2014 Pemertahanan Bahasa Daerah dalam Bingkai Keberagaman Budaya di Sulawesi Tenggara. Kendari: Kantor Bahasa Provinsi Sulawesi Tenggara. Kementerian Pendidikan dan Kebudayaan.

Liliweri, Alo. (2014). Pengantar Studi Kebudayaan. Bandung: Nusa Media.

Liliweri, Alo. (2016). Konfigurasi Dasar Teori-Teori Komunikasi Antarbudaya. Bandung: Nusa Indah.

Martina. (2020). "Tradisi Tonya' Menonya' Dayak Tobag” dipublikasikan dalam Inside Pontianak. https://insidepontianak.com/2020/01/26/tradisi-tonyamenonya-dayak-tobag/.

Muniah, Dad. (2015). "Kosakata Dalam Karya Sastra Sebagai Alat Pemertahanan Bahasa dan Sastra" dalam Proseding Kongres II Bahasa-Bahasa Tahun 
Tuah Talino

Tahun XIV Volume 14 Nomor 1 Edisi 31 Juli 2020

ISSN 0216-079X E-ISSN 2685-3043

Balai Bahasa Kalimantan Barat

2014 Pemertahanan Bahasa Daerah dalam Bingkai Keberagaman Budaya di Sulawesi Tenggara. Kendari: Kantor Bahasa Provinsi Sulawesi Tenggara. Kementerian Pendidikan dan Kebudayaan.

Pusat Bahasa. (2007). Pedoman Umum Pembentukan Istilah. Departemen Pendidikan dan Kebuadayaan. Jakarta: Pusat Bahasa.

Sibarani, Robert. (2015). "Pendekatan Antropolinguistik terhadap Kajian Tradisi LIsan" dalam Jurnal RETORIKA, Volume 1, Nomor 1, April 2015

Tim Penyusun. (2014). Kamus Besar Bahasa Indonesia. Edisi Keempat. Departemen Pendidikan dan Kebudayaan. Pusat Bahasa. 